\title{
Detection of IgG antibody during the follow-up in patients with COVID-19 infection
}

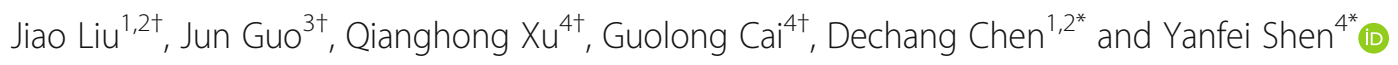

Although most patients with COVID-19 in China have been cured and discharged, we noticed a small proportion of these patients had re-positive RT-PCR test during the follow-up period [1]. The causes of this re-infection remain unclear. In common COVID19 cases [2], both the IgM and IgG antibodies significantly increased within a short period. However, in a case series report [3], the IgG was relatively low in re-infected COVID-19 cases. Thus, we investigated the IgG status in recovered patients during the follow-up period.

This retrospective study was performed in Wuhan JiangBei Hospital, China. COVID-19 infection was confirmed by the RT-PCR test. The IgM and IgG antibodies were detected using colloidal immunization methods. Only cured patients were included in this analysis. Patient consent was waived due to the retrospective nature. The ethics committee of Wuhan JiangBei Hospital approved this study.

During follow-up, only simple tests were performed, such as blood routine examination, antibody test, and chest computed tomography $(\mathrm{CT})$. For accuracy, missing data were not imputed.

Continuous variables were presented as mean \pm standard deviation, and Student's $t$ test was used unless indicated. Categorical data were compared using the chisquare test. $p<0.05$ was considered statistically

\footnotetext{
* Correspondence: cdcshjt@126.com; snow.shen@hotmail.com

${ }^{\dagger}$ Jiao Liu, Jun Guo, Qianghong Xu, and Guolong Cai are listed as co-first authors.

'Department of Critical Care Medicine, Ruijin Hospital, Shanghai Jiao Tong University School of Medicine, No.197 Ruijin 2nd Road, Shanghai, China

${ }^{4}$ Department of Critical Care Medicine, Zhejiang Hospital, No. 12, Linyin Road, Hangzhou 310000, Zhejiang, People's Republic of China

Full list of author information is available at the end of the article
}

significant. All statistical analyses were performed using STATA 14.0.

We studied 484 patients with positive IgG, the minimum period from onset to IgG detection was 10 days, and the maximum period was 100 days (Fig. 1). Meanwhile, $18 \%$ of these patients had negative IgG results, and this was confirmed by more than two IgG tests in 37 patients. The mean duration from onset to IgG test was close between positive and negative IgG groups $(50.5 \pm 14.8$ vs. $43.3 \pm 15.0$, days).

Further, compared to the negative IgG group, both the lymphocyte $(1.3 \pm 0.0$ vs. $1.6 \pm 0.1, p=0.001)$ and neutrophil counts $(3.5 \pm 1.6$ vs. $5.0 \pm 3.0, p<0.001)$ were lower in the positive group. Besides, the percent of abnormal CT findings at follow-up was higher in the positive IgG group $(259 / 372$ vs. $22 / 64, p<0.001)$ (Table 1).

Re-infection with COVID-19 in recovered patients has been occasionally encountered in clinical practice. Weak evidence [3] indicated that the IgG level was low in these re-infected COVID-19 cases. As IgG plays a critical role in immune response, understanding IgG status in recovered patients is necessary for preventing re-infections. In the current study, we found that $18 \%$ of the recovered patients had negative IgG. The mechanism remains unclear. However, we also found that compared to the positive group, the lymphocyte on hospital admission was higher in the negative group. Evidence $[4,5]$ has indicated that lymphocyte count is an independent predictor for COVID-19 severity. Thus, we inferred that compared to patients with positive IgG, those with negative IgG might have relatively mild COVID-19 infection, and the slight impact on their immune system leads to 


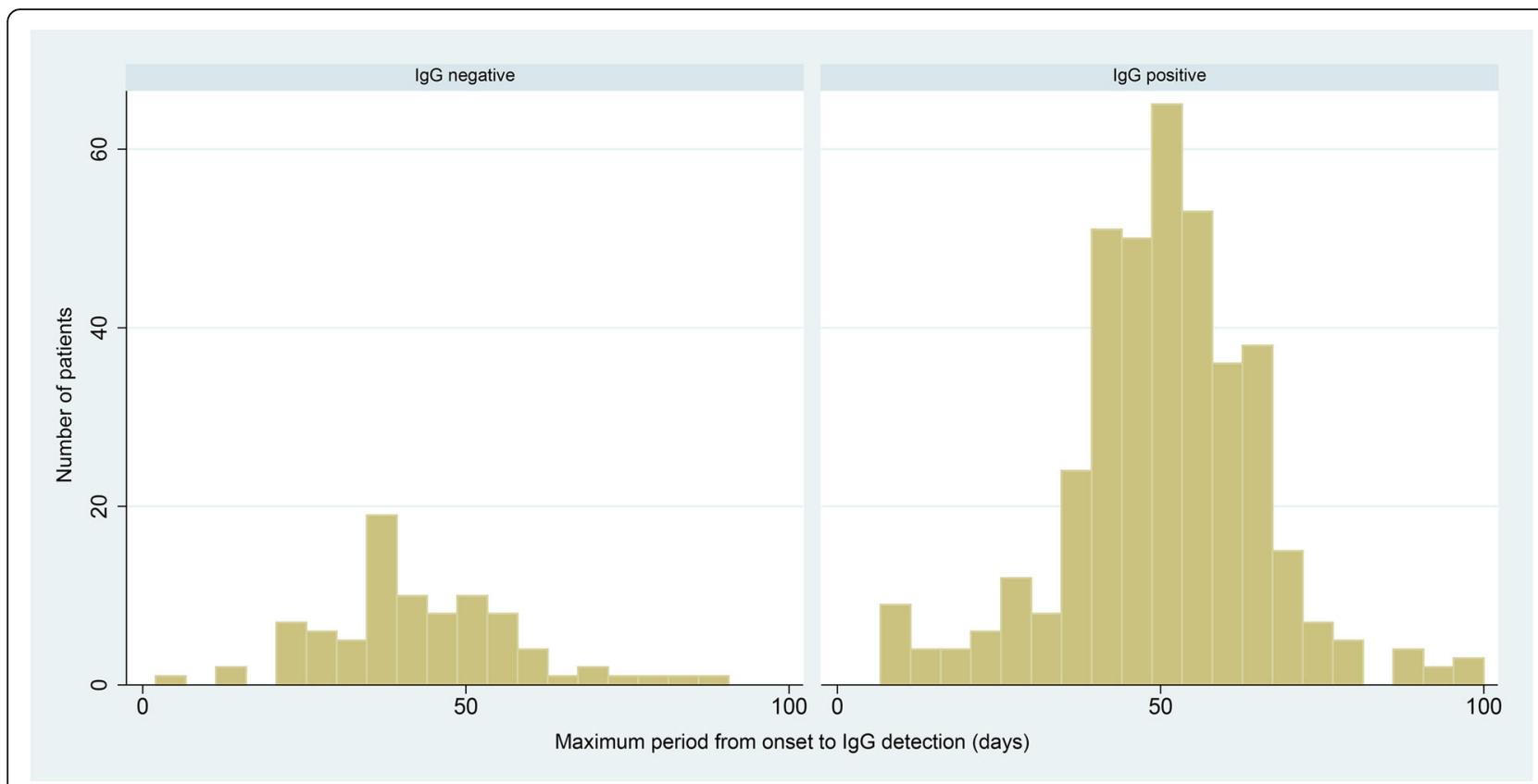

Fig. 1 Maximum period from disease onset to lgG detection in the negative and positive lgG groups

Table 1 Comparisons between patients with positive and negative IgG antibody

\begin{tabular}{|c|c|c|c|c|}
\hline Variables & $\begin{array}{l}\text { Positive } \\
\lg G(n=397)\end{array}$ & $\begin{array}{l}\text { Negative lgG } \\
(n=87)\end{array}$ & $\begin{array}{l}\text { Negative lgG } \\
(\geq 2 \text { tests }) \\
(n=37)\end{array}$ & $p$ \\
\hline Age (years) & $51.2 \pm 13.9$ & $49.6 \pm 17.2$ & $51.8 \pm 19.4$ & 0.365 \\
\hline Gender (male, \%) & $190(47.8)$ & $43(49.4)$ & $13(35.1)$ & 0.791 \\
\hline $\begin{array}{l}\text { White blood cell } \\
\text { count on admission }\end{array}$ & $5.3 \pm 1.8$ & $7.1 \pm 3.1$ & $6.9 \pm 2.7$ & $<0.001$ \\
\hline $\begin{array}{l}\text { Lymphocyte count } \\
\text { on admission }\end{array}$ & $1.3 \pm 0.0$ & $1.6 \pm 0.1$ & $1.6 \pm 0.7$ & 0.001 \\
\hline $\begin{array}{l}\text { Neutrophil count } \\
\text { on admission }\end{array}$ & $3.5 \pm 1.6$ & $5.0 \pm 3.0$ & $4.7 \pm 2.5$ & $<0.001$ \\
\hline $\begin{array}{l}\text { White blood cell } \\
\text { count at follow-up }\end{array}$ & $6.3 \pm 1.7$ & $6.5 \pm 1.8$ & $6.2 \pm 1.8$ & 0.387 \\
\hline $\begin{array}{l}\text { Lymphocyte count } \\
\text { at follow-up }\end{array}$ & $2.1 \pm 0.6$ & $2.1 \pm 0.6$ & $2.0 \pm 0.7$ & 0.738 \\
\hline $\begin{array}{l}\text { Neutrophil count } \\
\text { at follow-up }\end{array}$ & $3.7 \pm 1.4$ & $3.9 \pm 1.4$ & $3.6 \pm 1.3$ & 0.296 \\
\hline $\begin{array}{l}\text { Maximum duration } \\
\text { of lgG test }\end{array}$ & $50.5 \pm 14.8$ & $43.3 \pm 15.0$ & $50.6 \pm 12.1$ & $<0.001$ \\
\hline $\begin{array}{l}\text { Maximum duration } \\
\text { of lgG test*, median } \\
\text { (min and max value) }\end{array}$ & $51(10-100)$ & $42(2-90)$ & $50(28-90)$ & $<0.001$ \\
\hline $\begin{array}{l}\text { Abnormal CT findings } \\
\text { at follow-up\# } \\
\text { (which indicate } \\
\text { residual infection) }\end{array}$ & $259 / 372$ & $22 / 64$ & $10 / 32$ & $<0.001$ \\
\hline
\end{tabular}

All comparisons were made between positive IgG and negative IgG groups IgG immunoglobulin G, CT computed tomography

*Presented as median (minimum and maximum value), compared using rank-sum test

\#Any chest CT findings that suggested residual infection during follow-up were defined as abnormal the higher lymphocyte and negative IgG during the follow-up period. This hypothesis was also supported by the CT finding that the residual infection on chest CT disappears more quickly in patients with negative IgG. If this is the case, the risk of re-infection of COVID-19 in these patients should be carefully assessed in the later stage of epidemic prevention.

This study was limited by the qualitative IgG tests and short follow-up period. Further study should focus on the time-dependent change of the antibody level and the identification of those who are still at risk of re-infection in recovered patients.

\section{Acknowledgements}

Not applicable.

\section{Authors' contributions}

Y.S. and D.C. came up with the question, and J.L. and J.G. were responsible for the data extraction and analysis. Q.X. and G.C. were responsible for writing. The authors read and approved the final manuscript.

Funding

None.

\section{Availability of data and materials}

All the data were available from the corresponding author on a reasonable request.

Ethics approval and consent to participate

Not applicable.

Consent for publication

Not applicable.

Competing interests

None. 


\section{Author details}

'Department of Critical Care Medicine, Ruijin Hospital, Shanghai Jiao Tong University School of Medicine, No.197 Ruijin 2nd Road, Shanghai, China. ${ }^{2}$ Department of Critical Care Medicine, Ruijin Hospital North, Shanghai Jiao Tong University School of Medicine, No.999 Xiwang Road, Shanghai, China. ${ }^{3}$ Department of Critical Care Medicine, Huazhong University of Science and Technology Union Jiangbei Hospital, 111 Success Avenue, Wuhan, China.

${ }^{4}$ Department of Critical Care Medicine, Zhejiang Hospital, No. 12, Linyin Road, Hangzhou 310000, Zhejiang, People's Republic of China.

Received: 7 June 2020 Accepted: 1 July 2020

Published online: 20 July 2020

\section{References}

1. Lan L, Xu D, Ye G, Xia C, Wang S, Li Y, Xu H. Positive RT-PCR test results in patients recovered from COVID-19. JAMA. 2020;323(15):1502-3.

2. Zhang W, Du RH, Li B, Zheng XS, Yang XL, Hu B, Wang YY, Xiao GF, Yan B, Shi ZL, et al. Molecular and serological investigation of 2019-nCoV infected patients: implication of multiple shedding routes. Emerg Microbes Infect. 2020;9(1):386-9.

3. Qin W, Sun G, Zhang Y, et al. Patients with COVID-19 testing positive for nucleic acids of SARS-CoV2 in re-examination after discharge from hospital: an analysis of three cases. Chinese J Virol. 2020;10(2);1-4.

4. Wang F, Nie J, Wang H, Zhao Q, Xiong Y, Deng L, Song S, Ma Z, Mo P, Zhang $Y$. Characteristics of peripheral lymphocyte subset alteration in COVID-19 pneumonia. J Infect Dis. 2020;221(11):1762-9.

5. Azkur AK, Akdis M, Azkur D, Sokolowska M, van de Veen W, Bruggen MC, O'Mahony L, Gao Y, Nadeau K, Akdis CA. Immune response to SARS-CoV-2 and mechanisms of immunopathological changes in COVID-19. Allergy. 2020;75(7):1564-81.

\section{Publisher's Note}

Springer Nature remains neutral with regard to jurisdictional claims in published maps and institutional affiliations.

Ready to submit your research? Choose BMC and benefit from:

- fast, convenient online submission

- thorough peer review by experienced researchers in your field

- rapid publication on acceptance

- support for research data, including large and complex data types

- gold Open Access which fosters wider collaboration and increased citations

- maximum visibility for your research: over $100 \mathrm{M}$ website views per year

At $\mathrm{BMC}$, research is always in progress.

Learn more biomedcentral.com/submissions 